Jurnal Kajian Bimbingan dan Konseling

Vol. 1, No. 1, 2016, hlm. 27-32

Tersedia Online di http://journal.um.ac.id/index.php/bk



\title{
PENGEMBANGAN MEDIA LETTER SHARING UNTUK MENINGKATKAN KETERAMPILAN KOMUNIKASI SISWAINTROVERT
}

\author{
Elian Iwi Afifah, Triyono, Yuliati Hotifah \\ Bimbingan dan Konseling-Fakultas Ilmu Pendidikan-Universitas Negeri Malang-Jl. Semarang No. 5 Malang \\ E-mail: elianiwiafifah@yahoo.com
}

\begin{abstract}
Communication skills are the most important things for teenagers. There is a leaning that the teenagers who have low communication skills can be called as someone who is introvert personality. People who are introvert personality tend to be difficult to communicate and express verbally. The purpose of developing letter sharing media is to improve communication skills of introvert student. This research is development research by adopting Borg and Gall research model. The development result showed that this product has the criteria of usefulness, feasibility, accuracy, and attractiveness and appropriate when used to facilitate students to express communication skills in writing.
\end{abstract}

Keywords: communication skills; letter sharing media; introvert personality

\begin{abstract}
Abstrak: Keterampilan komunikasi merupakan hal yang terpenting bagi remaja. Terdapat kecenderungan bahwa remaja yang memiliki keterampilan komunikasi yang rendah dapat dikatakan sebagai seseorang yang berkepribadian introvert. Orang yang berkepribadian introvert cenderung sulit berkomunikasi dan sulit mengungkapkan secara lisan. Pengembangan media letter sharing ini bertujuan untuk meningkatkan keterampilan komunikasi siswa introvert. Penelitian ini merupakan penelitian pengembangan dengan mengadopsi model penelitian Borg and Gall. Hasil pengembangan menunjukkan bahwa produk ini mempunyai kriteria kegunaan, kelayakan, ketepatan, kemenarikan dan sesuai apabila digunakan untuk memfasilitasi siswa dalam mengekspresikan keterampilan komunikasi secara tertulis.
\end{abstract}

Kata kunci: keterampilan komunikasi; media letter sharing; kepribadian introvert

Pada usia remaja, kondisi psikis individu masih kurang stabil sehingga pada usia tersebut tepatnya pada jenjang SMP, kebanyakan dari mereka masih belum mengetahui potensi yang dimiliki, apa yang selayaknya dilakukan, dan kapan mereka harus bertindak dalam mengambil keputusan. Santrock (2003) menyatakan bahwa individu mengalami perubahan dalam tiga domain, yaitu proses biologis, proses kognitif, dan proses sosio-emosional. Dalam masa perubahan tersebut diperlukan adanya pendampingan pada diri remaja, baik dari lingkungan keluarga maupun lingkungan sekolah. Hal tersebut diperlukan karena tiga domain perubahan tersebut sangat berpengaruh besar terhadap keterampilan komunikasi yang ditampakkan oleh remaja.

Keterampilan komunikasi merupakan salah satu cara bagi remaja untuk mengungkapkan sesuatu yang ada di pikirannya. Terdapat kecenderungan bahwa remaja yang memiliki keterampilan komunikasi yang rendah dapat dikatakan sebagai seseorang yang berkepribadian introvert. Kepribadian yang seperti itu 
cenderung menutup diri dengan orang lain dan lebih memilih untuk memendam apa yang dirasakan. Dengan adanya keterampilan komunikasi pada diri remaja, maka remaja akan benar-benar dapat mengekspresikan apa yang diinginkan dan orang lain juga akan mengetahui apa yang sebenarnya diinginkan oleh remaja tersebut. Ketika hal itu terjadi, maka dia juga dapat mengevaluasi mengenai baik buruknya apa yang telah diungkapkan, sehingga dia akan dapat memperbaiki sikap atau tingkah laku yang kurang baik dan pada akhirnya remaja tersebut akan dapat berkembang secara optimal.

Seperti pada siswa di SMPN 2 Malang, sebagian dari mereka masih berkepribadian introvert. Berdasarkan hasil wawancara dengan salah satu guru BK, beliau menjelaskan bahwa masih banyak siswa yang memiliki kepribadian introvert. Menurut Ibu Endang selaku salah satu konselor, menjelaskan bahwa remaja yang berkepribadian introvert, lebih senang menyendiri, mengalami kesulitan dalam mencari kelompok belajar, tertutup, tidak memiliki teman dekat lebih dari seorang. Selain itu, mereka juga sulit mengungkapkan pendapat secara verbal dan mereka juga memiliki kepercayaan yang rendah terhadap teman.

Penelitian yang dilakukan oleh Tristiana (2012), pada kelas VII F di SMPN 1 Malang, terdapat 50\% siswa berkepribadian introvert dan $50 \%$ berkepribadian extrovert. Siswa yang berkepribadian introvert tinggi sebesar 21,43\%. Persentase ini sangat jauh berbeda dengan siswa yang berkepribadian extrovert tinggi. Hasil penelitian menunjukkan bahwa siswa yang berkepribadian extrovert tinggi hanya 3,57\%. Berdasarkan data hasil penelitian itu, dapat diambil kesimpulan bahwa jumlah siswa yang berkepribadian introvert dalam klasifikasi tinggi lebih banyak daripada jumlah siswa extrovert klasifikasi tinggi.

Pada hakikatnya, seseorang berkecendurungan memiliki masalah baik masalah pribadi, sosial, karier, maupun akademik. Seseorang yang memiliki keterampilan komunikasi yang baik, maka dia akan berusaha untuk mengungkapkan hal tersebut. Dengan adanya keterampilan komunikasi pada diri remaja, maka remaja akan benar-benar dapat mengekspresikan apa yang diinginkan dan orang lain juga akan mengetahui apa yang sebenarnya diinginkan oleh remaja tersebut. Ketika hal itu terjadi, maka dia juga dapat mengevaluasi mengenai baik buruknya apa yang telah diungkapkan, sehingga dia akan dapat memperbaiki sikap atau tingkah laku yang kurang baik dan pada akhirnya remaja tersebut akan dapat berkembang secara optimal.

Media letter sharing merupakan produk cetak yang digunakan dalam membantu siswa introvert untuk mengembangkan keterampilan berkomunikasinya. Berdasarkan pendekatan konseling naratif, manusia dipandang sebagai makhluk yang menilai dan menginternalisasi diri sendiri dengan menceritakan cerita kehidupannya. Kebanyakan cerita tersebut menyoroti kualitas negatif mengenai individu ataupun situasi kehidupan mereka dan sangat mengganggu atau membuat depresi (Gladding, 2012:286). Worden dalam Gladding (2012:286) menyatakan bahwa konselor naratif menekankan bahwa pengetahuan atau arti dibentuk melalui interaksi sosial.

Sementara itu, Walsh \& Keenan dalam (Gladding, 2012:286) berpendapat bahwa pendekatan naratif memandang konselor sebagai kolaborator dan ahli dalam memberikan pertanyaan. Konselor menggunakan alasan negatif, yang dikarakteristikkan kisah-kisah, keberartian, dan kehidupan, sebagai upaya untuk membantu konseli mendefinisikan kembali kehidupan dan hubungannya melalui naratif baru. Pendekatan ini menekankan pada pengembangan kisah alternatif dan unik dalam kehidupan seseorang, dengan harapan bahwa konseli akan menemukan pilihan dan strategi baru untuk kehidupannya (Gladding, 2012:287).

Berpedoman pada teori naratif, maka dikembangkan sebuah media letter sharing, di mana produk ini merupakan produk cetak yang digunakan dalam membantu siswa introvert untuk mengembangkan kemampuan berkomunikasinya. Siswa introvert mempunyai kesulitan dalam bersosialisasi dan berinteraksi dengan orang lain di sekitarnya, hal ini dikarenakan individu introvert mencurahkan fokus lebih ke dalam diri dari pada di luar dirinya, individu introvert kurang memberikan perhatian lebih terhadap orang-orang yang ada di sekitarnya dan lebih merasa nyaman dalam kesendirian serta tergolong orang yang mempunyai sifat pemalu.

Merubah siswa yang berkepribadian introvert menjadi siswa yang berkepribadian extrovert bukanlah cara yang tepat, karena pada dasarnya kita tidak dapat merubah kepribadian seseorang. Sehubungan dengan pernyataan tersebut, siswa yang berkepribadian introvert memerlukan sebuah media untuk meningkatkan keterampilan komunikasinya. Media letter sharing ini akan membantunya untuk mengekspresikan perasaan dan juga pengalamannya ke dalam bentuk tulisan. Oleh karena itu, penting dilakukan "Pengembangan Media Letter Sharing untuk Meningkatkan Keterampilan Komunikasi Siswa Introvert”. 


\section{METODE}

Penelitian ini merupakan penelitian pengembangan (Research and Development). Pengembangan media letter sharing untuk meningkatkan keterampilan komunikasi siswa introvert mengadaptasi dari strategi pengembangan Borg dan Gall (2003) yang memiliki tujuh tahap.

Tahap pertama yang ditempuh dalam mengembangkan media adalah identifikasi kebutuhan. Pada tahap ini peneliti melakukan analisis permasalahan utama pada karakteristik siswa di SMP Negeri 2 Malang. Permasalahan yang akan diteliti adalah siswa yang berkepribadian introvert di sekolah tersebut. Langkah yang ditempuh dalam analisis awal ini meliputi: (1) melakukan wawancara dengan konselor di sekolah tersebut mengenai jenis-jenis kepribadian siswa di sekolah tersebut, (2) konselor memberikan data tentang identitas siswa yang berkepribadian introvert, (3) memberikan kuisioner kepada siswa introvert untuk mengetahui lebih lanjut mengenai karakteristik siswa introvert, (4) melakukan tahapan analisis kebutuhan siswa. Tujuan dilakukannya tahap ini adalah menyamakan persepsi antara karakteristik siswa introvert dengan pemikiran peneliti agar hasil pengembangan media dapat maksimal.

Tahap yang kedua adalah perumusan tujuan. Tujuan pengembangan media letter sharing dimaksudkan agar siswa introvert memperoleh gambaran tentang pentingnya keterampilan komunikasi dan agar siswa introvert memperoleh gambaran tentang bagaimana cara meningkatkan keterampilan berkomunikasi.

Tahap ketiga adalah pembuatan media. Pada tahap ini, peneliti mengumpulkan sumber-sumber yang akan digunakan dalam pengembangan media, baik dari buku maupun program yang akan digunakan. Format media yang akan dikembangkan adalah meliputi: sampul atau cover, identitas pemilik buku letter sharing, pendahuluan, petunjuk penggunaan, lembar catatan harian, lembar umpan balik atau feedback konselor, dan lembar kesimpulan.

Tahap keempat adalah pembuatan prototype. Prototype media letter sharing ini dilakukan sebelum menyusun media yang sesungguhnya. Pembuatan prototype bertujuan sebagai dasar penyusunan media. Adapun hal-hal yang dikembangkan terlebih dahulu adalah pertanyaan-pertanyaan yang menjadi fokus dalam membimbing siswa introvert untuk meningkatkan keterampilan berkomunikasi.

Tahap kelima yaitu validasi produk. Validasi produk dilakukan sebelum digunakan untuk keperluan uji coba. Validasi produk ini bertujuan untuk mengetahui kelayakan media, baik dari segi tampilan, isi, maupun pertanyaan-pertanyaan yang menjadi fokus dalam penelitian. Validator produk meliputi tiga orang dosen bimbingan dan konseling serta tiga orang konselor.

Tahap keenam adalah tahap Revisi. Revisi bertujuan untuk memperbaiki atau menyempurnakan media yang dihasilkan. Apabila produk yang sudah direvisi masih perlu direvisi, maka peneliti melakukan validasi ulang, namun jika produk pengembangan yang berupa media letter sharing tersebut dinyatakan layak, maka hanya dilakukan revisi sesuai dengan komentar dan saran yang diberikan validator.

Tahap ketujuh merupakan tahap terakhir dari pengembangan media. Tahap ini adalah tahap pengemasan. Letter sharing yang dikembangkan berupa media cetak dan siswa dapat menggunakan media tersebut. Selain siswa, konselor juga dapat menggunakan media letter sharing ini untuk mengevaluasi dan menginterpretasi hasil kerja siswa

Uji coba produk dilakukan kepada siswa introvert di SMPN 2 Malang. Uji coba ini merupakan uji coba terbatas yang dilakukan kepada kelompok kecil sebagai pengguna media. Uji coba kelompok kecil dilakukan oleh beberapa siswa SMP yang berkepribadian introvert. Data yang diperoleh adalah data angka dan verbal. Data angka berupa nilai modus yang diperoleh dari angket keterbacaan uji kelompok kecil, sedangkan data verbal diperoleh dari komentar atau perasaan siswa setelah menggunakan media letter sharing. Data angka berupa nilai modus yang diperoleh dari angket keterbacaan disusun dengan skala. Angket yang didapatkan dari skala ini berkisar angka satu sampai angka empat.

Instrumen pengumpulan data dalam pengembangan media letter sharing menggunakan instrumen berupa angket. Angket berisi sejumlah pernyataan tertulis yang digunakan untuk memperoleh informasi dari ahli dan pengguna produk mengenai kelayakan media yang dikembangkan. Instrumen pengumpulan data yang digunakan oleh ahli layanan BK dan calon pengguna produk berupa angket tertutup dan tidak langsung, yaitu berbentuk check list dan uraian singkat. Angket ini berguna untuk mengetahui tingkat kelayakan media yang dikembangkan. Angket yang digunakan terdiri dari dua bagian, yaitu lembar penilaian yang berupa 
skala bertingkat yang terdiri dari pertanyaan yang diikuti kolom-kolom atau pilihan-pilihan yang menunjukkan tingkatan kesesuaian produk yang dikembangkan, jawaban angket menggunakan skala bertingkat dengan kategori pilihan dan lembar kritik dan saran yang diisi oleh ahli sebagai masukan atau saran untuk memperbaiki media.

Instrumen pengumpulan data yang digunakan oleh uji kelompok kecil berupa angket tertutup, yaitu berbentuk check list. Angket ini berguna untuk mengetahui kemenarikan dan kebermanfaatan media yang dikembangkan. Angket yang digunakan berupa lembar penilaian yang berupa skala bertingkat (rating scale). Yaitu pertanyaan yang diikuti pilihan-pilihan yang menunjukkan tingkatan kemenarikan dan kebermanfaatan produk yang dikembangkan. Jawaban angket menggunakan skala bertingkat dengan kategori pilihan. Selain itu juga terdapat kolom tanggapan dan saran yang diisi oleh siswa.

Teknik analisa data yang digunakan adalah data angka dan verbal. Data angka dan data verbal diperoleh dari hasil uji ahli layanan BK, uji calon pengguna produk, dan uji kelompok kecil berupa pengisian angket yang sudah disediakan dan masukan, saran, dan komentar yang dianalisis secara deskriptif untuk penyempurnaan produk lembar kerja letter sharing.

Data angka dianalisis dengan menggunakan modus (mengambil skor yang paling banyak dipilih dari subjek), sedangkan data verbal dianalisis menggunakan teknik analisis deskriptif yang diperoleh dari hasil saran atau tanggapan dari ahli serta calon pengguna produk.

\section{HASIL}

Hasil akhir dari pengembangan ini adalah produk yang berupa lembar kerja letter sharing bagi siswa SMP yang terdiri dari panduan konselor dan siswa. Konselor dapat menggunakan produk ini untuk menerapkan layanan konseling dengan menggunakan media letter sharing untuk meningkatkan keterampilan komunikasi siswa introvert, sedangkan bagi siswa dapat digunakan sebagai media untuk meningkatkan pemahaman mengenai pentingnya keterampilan komunikasi dan memotivasi siswa untuk berlatih mengungkapkan yang ingin diungkapkan secara verbal.

Data angka merupakan data yang diperoleh dari penilaian ahli berdasarkan isian angket skala penilaian. Skala penilaian ini merupakan alat ukur dengan empat indikator penilaian yaitu, kegunaan, kelayakan, ketepatan, dan kemenarikan. Penilaian data verbal diperoleh melalui tanggapan, saran, maupun kritik dari ahli.

Hasil uji ahli BK terhadap aspek kegunaan dapat diklasifikasikan berguna, layak untuk aspek kelayakan, sangat tepat untuk aspek ketepatan, dan menarik untuk aspek kemenarikan. Berdasarkan penilaian hasil uji calon pengguna produk, terhadap aspek kegunaan dapat diklasifikasikan berguna, layak untuk aspek kelayakan, sangat tepat untuk aspek ketepatan, dan menarik untuk aspek kemenarikan. Selain itu, terdapat juga penilaian dari uji kelompok kecil. Hasil uji kelompok kecil terhadap aspek kegunaan dapat diklasifikasikan sangat berguna, sangat layak untuk aspek kelayakan, sangat tepat untuk aspek ketepatan, dan sangat menarik untuk aspek kemenarikan.

Berdasarkan penilaian yang dilakukan oleh ahli BK, menyebutkan bahwa pada petunjuk penggunaan sebaiknya disertakan penjelasan bahwa inventori un-tuk mengetahui siswa introvert dan extrovert terdapat pada lampiran dan perlu dijelaskan pula bahwa pengisian reinforcement dilakukan setelah konselor mengevaluasi. Background sebaiknya di buat simple. Selain itu pada tabel evaluasi, garis pada tabelnya terlalu tebal. Perlu diperhatikan juga logo um pada cover, sebaiknya diperkecil.

Penilaian data verbal yang dilakukan oleh calon pengguna produk, menyebutkan bahwa pada uraian lembar evaluasi dan interpretasi lebih baik diawali dengan petunjuk lebih dahulu. Waktu yang digunakan kurang efektif karena produk ini hanya digunakan untuk siswa introvert saja. Sebaiknya juga ditambahi gambar-gambar agar siswa lebih termotivasi. Selain itu, pada uraian pendahuluan hendaknya disampaikan mengenai tujuan dan manfaat letter sharing.

Penilaian data verbal dari kelompok kecil menyatakan bahwa produk lembar kerja letter sharing ini dapat membantu mereka dalam berkomunikasi secara tertulis mengenai pengalaman yang mereka alami. Selain itu, produk ini menurut mereka merupakan produk yang sangat menarik. Mereka juga mengatakan bahwa produk letter sharing ini mudah dipahami. Namun, mereka menginginkan gambar yang terdapat dalam produk ini adalah gambar kartun. 
Siswa mengisi lembar kerja letter sharing selama 14 hari. Selama kegiatan ini, siswa didampingi oleh konselor. Hasil yang diperoleh berdasarkan penelitian menyebutkan bahwa siswa cukup tertarik dalam mengikuti kegiatan pengisian lembar kerja letter sharing ini. Hal ini dapat dibuktikan dengan persentase keterbukaan yang diperoleh siswa. Pada hari ke $1-8$ persentase yang diperoleh menunjukkan kenaikan, namun setelah dianalisis terjadi penurunan pada hari ke-9 sampai hari ke-14 secara signifikan. Hal ini diduga bahwa siswa mengalami kejenuhan pada hari tersebut.

\section{PEMBAHASAN}

Peneliti mengembangkan sebuah produk berupa lembar kerja letter sharing bagi siswa SMP. Produk ini berupa media cetak yang berbentuk blocknote, yang berisikan identitas siswa, petunjuk penggunaan, butir pertanyaan, feedback dalam bentuk reinforcement dari konselor, dan kesimpulan tahap perkembangan siswa selama dua minggu dalam menggunakan letter sharing. Media yang berupa letter sharing ini divalidasi oleh dosen bimbingan dan konseling, konselor, dan beberapa siswa dalam bentuk uji kelompok kecil. Proses validasi meliputi validasi kegunaan, kelayakan, ketepatan dan kemenarikan.

Produk yang berupa letter sharing terdiri atas dua jenis, (1) lembar kerja letter sharing untuk konselor, (2) lembar kerja letter sharing untuk siswa. Format penulisan lembar kerja pada letter sharing untuk konselor, meliputi: (1) daftar isi, (2) pendahuluan, (3) petunjuk penggunaan, (4) alur penggunaan lembar kerja siswa, (5) petunjuk evaluasi, (6) lembar evaluasi, (7) petunjuk skoring dan interpretasi, (8) lembar skoring dan interpretasi, (9) instrumen. Format penulisan lembar kerja pada letter sharing untuk siswa, meliputi: (1) identitas siswa, (2) pendahuluan, (3) petunjuk penggunaan, (4) pertanyaan-pertanyaan dan reinforcement, (5) kesimpulan.

Setelah produk selesai dibuat, kemudian diuji oleh ahli BK, calon pengguna produk (konselor), dan uji kelompok kecil (siswa). Hal ini untuk mengetahui kevalidan dari aspek kegunaan, kelayakan, ketepatan, dan kemenarikan secara keseluruhan. Hasil uji coba menunjukkan bahwa produk lembar kerja letter sharing ini menurut hasil uji ahli BK dan uji calon pengguna produk menyatakan bahwa produk ini termasuk dalam kriteria sangat berguna, layak, sangat tepat, dan menarik. Sedangkan uji kelompok kecil menunjukkan bahwa, produk letter sharing termasuk dalam kriteria sangat berguna, sangat layak, sangat tepat, dan sangat menarik.

Ahli BK berpendapat bahwa secara umum bagus dan setelah direvisi maka produk lembar kerja letter sharing layak untuk digunakan dalam peningkatan keterampilan komunikasi siswa introvert. Calon pengguna produk berpendapat bahwa secara umum bagus dan setelah direvisi maka produk lembar kerja letter sharing layak untuk digunakan dalam peningkatan keterampilan komunikasi siswa introvert. Dengan demikian, ahli BK dan calon pengguna produk menyatakan perlu dilakukan revisi untuk memperbaiki produk agar lebih sempurna dan sesuai dengan kebutuhan siswa.

Revisi dilakukan berdasarkan saran dari ahli BK 1, BK 2, BK 3, calon pengguna produk 1, calon pengguna produk 2, dan calon pengguna produk 3. Revisi ahli BK yaitu pada petunjuk penggunaan untuk konselor sebaiknya disertakan penjelasan bahwa inventori untuk mengetahui siswa introvert dan extrovert terdapat pada lampiran. Perlu disertakan pula penjelasan bahwa pengisian reinforcement dilakukan setelah konselor mengevaluasi hasil kerja siswa dalam mengisi lembar kerja letter sharing. Sebaiknya pada lembar kerja siswa, perlu dijelaskan pada petunjuk penggunaan bahwa pengisian lembar kerja letter sharing ini berlangsung selama 14 hari.

Ada beberapa saran revisi dari calon pengguna produk yaitu pada produk lembar kerja letter sharing untuk konselor, lebih baik diawali dengan petunjuk lebih dahulu. Waktu yang digunakan kurang efektif karena produk ini hanya digunakan untuk siswa introvert saja. Sebaiknya juga ditambahi gambar-gambar agar siswa lebih termotivasi. Hendaknya disampaikan mengenai tujuan dan manfaat letter sharing pada pendahuluan.

Uji kelompok kecil dilakukan oleh siswa dengan menilai produk lembar kerja letter sharing dari segi kegunaan, kelayakan, ketepatan, dan kemenarikan. Tetapi ada beberapa saran dari uji kelompok kecil yakni gambar yang disertakan sebaiknya merupakan gambar kartun agar lebih memotivasi siswa untuk mengisi lembar kerja letter sharing. 
Penilaian dari ahli BK dan calon pengguna produk berupa data angka dan data verbal. Data angka dianalisis menggunakan modus (mengambil skor yang paling banyak dipilih dari subjek), selain data angka, diperoleh juga data verbal yang berupa saran dan masukan, sehingga dapat diketahui bahwa hasil dari penilaian uji ahli layanan BK dan uji calon pengguna produk menunjukkan bahwa lembar kerja letter sharing ini dikategorikan berguna, layak, sangat tepat, dan menarik untuk dikembangkan.

Pengisian lembar kerja letter sharing dilakukan selama 14 hari. Berdasarkan hasil penelitian, menunjukkan bahwa setiap harinya selalu mengalami peningkatan keterbukaan. Pada hari ke 1-8 menunjukkan bahwa persentase keterbukaan meningkat, namun setelah dianalisis, terjadi penurunan pada hari ke 9-14 secara signifikan. Penurunan ini diduga karena adanya kejenuhan yang dialami oleh siswa.

Reber (dalam Syah, 2011:162) menyebutkan bahwa kejenuhan belajar ialah rentang waktu tertentu yang digunakan untuk belajar, tetapi tidak mendatangkan hasil. Selain itu, kejenuhan juga dapat terjadi karena proses belajar siswa telah sampai pada batas kemampuan jasmaniahnya karena bosan (boring) dan keletihan (fatigue) (Syah, 2011:163). Keadaan ini sejalan dengan fakta yang diperoleh dari hasil penelitian bahwa siswa diduga merasa jenuh apabila menceritakan pengalaman dengan topik yang sama selama 14 hari. Berdasarkan analisis dari hasil penelitian, dapat disimpulakan bahwa efektivitas penggunaan lembar kerja letter sharing hanya sampai pada hari ke 8, sehingga terminasi dapat dilakukan pada hari tersebut. Namun tidak menutup kemungkinan apabila digunakan di tempat lain dengan karakteristik siswa yang berbeda, maka penggunaan letter sharing bisa dilakukan sampai hari ke 14 .

Produk lembar kerja letter sharing bagi siswa SMP ini berguna untuk memfasilitasi siswa dalam mengekspresikan keterampilan komunikasi secara tertulis berdasarkan pengalaman yang dialami sehingga siswa introvert tidak dapat dipaksa untuk dapat berkomunikasi secara verbal walaupun sudah mengikuti kegiatan pengisian lembar kerja letter sharing ini. Namun produk ini juga memiliki kelemahan, yaitu penelitian dilakukan hanya sampai pada tahap uji kelompok kecil dan tidak sampai pada tahap akhir (desiminasi). Selain itu, uji kelompok kecil yang dilakukan hanya sampai pada kegunaan dan proses pengisian lembar kerja letter sharing, tidak sampai menguji keefektifan produk ini.

\section{SIMPULAN DAN SARAN}

\section{Simpulan}

Setelah di uji cobakan, produk ini memenuhi kriteria kegunaan, kelayakan, ketepatan, dan kemenarikan apabila digunakan untuk siswa SMP.

\section{Saran}

Saran-saran yang dikembangkan bagi konselor sekolah dan pengembang selanjutnya antara lain: (1) konselor diharapkan menggunakan produk lembar kerja letter sharing dalam memberikan layanan BK di bidang pribadi dan sosial. (2) konselor disarankan meminta bantuan konselor pendamping (konselor lain yang ada di sekolah) apabila kegiatan ini dilakukan dalam kelas besar. (3) bagi peneliti selanjutnya perlu dilakukan uji keefektifan dengan penelitian eksperimen dan/ atau penelitian tindakan bimbingan.

\section{DAFTAR RUJUKAN}

Borg, Walter R \& Gall, Meredith Damien. 2003. Educational Research. New York: Longman. Corey, G. 2009. Theory and Practice of Counseling and Psychotherapy. Belmont, CA : Brooks/Cole. Gladding, Samuel T. 2012. Konseling Profesi yang Menyeluruh. Jakarta:Indeks.

Santrock, J. W. 2003. Adolescence (Perkembangan Remaja. Jakarta: Penerbit Erlangga.

Syah, Muhibbin. 2011. Psikologi Pendidikan. Bandung: PT Remaja Rosdakarya.

Tristiana, Ita. 2012. Analisis Kemampuan Siswa Kelas VII SMPN 1 Malang Tipe Kepribadian Ekstrovert dan Introvert dalam Menyelesaikan Masalah Matematika Berdasarkan Analisis Newman. Skripsi. Malang: Fakultas Matematika dan Ilmu Pengetahuan Program Studi Pendidikan Matematika. 